ORIGINAL ARTICLES

\title{
Prevalence of Overweight and Obesity among Children Six to Ten Years of Age in the North-East Health Region of Jamaica \\ BE Blake-Scarlett ${ }^{1,3}$, N Younger ${ }^{1}$, CA McKenzie ${ }^{1}$, J Van den Broeck ${ }^{2}$, C Powell ${ }^{1}$, S Edwards ${ }^{3}$, SS Win ${ }^{3}$, RJ Wilks ${ }^{1}$
}

\begin{abstract}
Objective: To estimate the prevalence and correlates of overweight and obesity among children six to ten years old in the North-East Health Region (NEHR) of Jamaica.

Methods: Weights and heights were measured in a representative sample of 5710 children between the ages of six and ten years in 34 schools between October 2008 and March 2009. Overweight and obesity were defined as body mass index (BMI) Z-score $>1 S D$ and $>2 S D$, respectively based on the World Health Organization (WHO)-endorsed age and gender-specific growth standards for children. Point prevalence estimates of overweight and obesity were calculated. Odds ratios (OR) and $95 \%$ confidence intervals (CI) were used to estimate associations between overweight and obesity and age, gender and school location.

Results: Overweight and obesity prevalence among children six to ten years old in NEHR, Jamaica, was $10.6 \%$ and $7.1 \%$, respectively. Overweight $(O R=1.11,95 \%$ CI: 1.04, 1.18) and obesity $(O R=1.17$, $95 \%$ CI: 1.08, 1.26) prevalence increased significantly with age. Overweight (OR $=1.51,95 \%$ CI: $1.27,1.80)$ and obesity $(O R=1.36,95 \%$ CI: 1.11, 1.67) prevalence was significantly higher among girls than boys. Children attending rural-public schools had less risk of being overweight $(O R=0.57$, 95\% CI: 0.46, 0.70) and obese (OR $=0.35,95 \%$ CI: $0.28,0.44)$ when compared with urban-public schools and private schools. Both overweight $(O R=2.11,95 \%$ CI: 1.60, 2.78) and obesity $(O R=1.68$, $95 \%$ CI: 1.24, 2.28) were significantly more common among children attending private schools. After adjusting for age and gender, the results still remained statistically significant.

Conclusions: Overweight/obesity prevalence among children six to ten years old in NEHR of Jamaica is $17.7 \%$ with older children and girls having higher rates. Children attending urban-public and private schools have higher prevalence than those attending rural schools. Appropriately targeted interventions are needed to combat this problem.
\end{abstract}

Keywords: Children six to ten years old, Jamaica, overweight/obesity, private schools, rural schools, urban schools

\section{Prevalencia del Sobrepeso y la Obesidad entre Niños de Seis a Diez Años de Edad en la Región Noreste de Atención a la Salud en Jamaica BE Blake-Scarlett ${ }^{1,3}$, N Younger ${ }^{1}$, CA McKenzie ${ }^{1}$, J Van den Broeck ${ }^{2}$, C Powell ${ }^{1}$, S Edwards ${ }^{3}$, SS Win ${ }^{3}$, RJ Wilks ${ }^{1}$}

\section{RESUMEN}

Objetivo: Estimar la prevalencia y los correlatos de sobrepeso y obesidad entre niños de seis a diez años en la región noreste de atención a la salud (RNAS) de Jamaica.

From: ${ }^{1}$ Tropical Medicine Research Institute, The University of the West Indies, Kingston 7, Jamaica, ${ }^{2}$ Centre for International Health, University of Bergen, Norway and ${ }^{3}$ Ministry of Health, Jamaica.
Correspondence: Dr BE Blake-Scarlett, Tropical Medicine Research Institute, The University of the West Indies, Kingston 7, Jamaica. E-mail: beverly.blakescarlett@mymona.uwi.edu 
Sujetos y Métodos: Se midió el peso y la altura en una muestra representativa de 5710 niños en edades entre seis y diez años, en 34 escuelas, entre octubre de 2008 y marzo de 2009. El sobrepeso y la obesidad se definieron como el indice de masa corporal (IMC) de puntuación $Z>1 S D$ y $>2 S D$, respectivamente, tomando como base las normas especificas de crecimiento por género y edad para los niños, aprobadas por la Organización Mundial de la Salud (OMS). Se calcularon los estimados de prevalencia puntual del sobrepeso y la obesidad. Se utilizaron los cocientes de probabilidades relativas (OR) e intervalos de confianza (IC) del 95\%, a fin de determinar las asociaciones entre el sobrepeso y la obesidad por un lado, y la edad, el género y lugar de la escuela, por otro lado.

Resultados: La prevalencia del sobrepeso y la obesidad entre los niños de seis a diez años en la $R N A S$, Jamaica, fue de $10.6 \%$ y 7.1\%, respectivamente. La prevalencia del sobrepeso (OR $=1.11, I C$ de 95\%: 1.04, 1.18) y de la obesidad (OR = 1.17, IC del 95\%: 1.08, 1.26) aumentó significativamente con la edad. La prevalencia del sobrepeso (OR $=1.51$, IC del 95\%: 1.27, 1.80) y la obesidad (OR= 1,36, IC de 95\%: 1.11, 1.67) fue significativamente mayor entre las hembras que entre los varones. Los niños que asistían a las escuelas públicas rurales tuvieron menos riesgo de tener sobrepeso (OR = 0.57, IC del 95\%: 0.46, 0.70) y ser obesos (OR =0.35, IC del 95\%: 0.28, 0.44) en comparación con los de las escuelas urbanas públicas o privadas. Tanto el sobrepeso (OR $=2.11, I C$ del 95\%: 1.60, 2.78) como la obesidad (OR = 1.68, IC del 95\%: 1.24, 2.28) fueron significativamente más frecuentes entre los niños que asisten a escuelas privadas. Después de ajustar por edad y género, los resultados continuaban siendo todavía estadísticamente significativos.

Conclusiones: La prevalencia del sobrepeso/obesidad entre niños de seis a diez años en la RNAS en Jamaica es de $17.7 \%$, correspondiendo las tasas más altas a las hembras, y a los niños o niñas de mayor edad. Los niños y niñas que asisten a escuelas urbanas públicas y privadas presentan una mayor prevalencia que los que asisten a escuelas rurales. Se necesitan intervenciones dirigidas adecuadamente a combatir este problema.

Palabras clave: Niños, Jamaica, sobrepeso/obesidad, escuelas privadas, escuelas rurales, escuelas urbanas

West Indian Med J 2013; 62 (3): 172

\section{INTRODUCTION}

Obesity, including childhood obesity is increasing globally. Worldwide, about $10 \%$ of school-aged children 5-17 years are reported to be overweight or obese. More than $60 \%$ of children who are overweight before puberty will be overweight in early adulthood (1-3). Overweight is defined as increased body weight in relation to height, when compared to the standard of acceptable or desirable weight (4). Obesity is defined as an excessive amount of weight in relation to height, with significant health consequences. Body mass index (BMI) for age and gender is also used to classify children as overweight and obese. For this study, overweight and obesity were defined as BMI Z-score $>1 \mathrm{SD}$ and $>2 \mathrm{SD}$, respectively based on the World Health Organization (WHO)endorsed age and gender specific growth standards $(3,4-6)$.

Population-based studies in primary school children in low- and middle-income settings are scarce, especially those that report rural-urban and private-public school comparisons. In a cross-sectional study of 1000 school children aged 7-12 years in Bapol, Islamic Republic of Iran, the prevalence of overweight/obesity and associated factors in urban schoolchildren was assessed by comparing BMI values to the BMI index for age and gender percentiles set by the Centers for Disease Control and Prevention (CDC) in the United States of America (USA). The prevalence of obesity and over- weight was $5.8 \%$ and $12.3 \%$, respectively. The prevalence was significantly lower in girls compared with boys (ageadjusted $\mathrm{OR}=0.69,95 \% \mathrm{Cl}$ : $0.50,0.96$ ) and higher among private-school compared with public-school educated students [age adjusted $\mathrm{OR}=2.17,95 \% \mathrm{Cl}: 1.47,3.18$ ] (7).

Investigation of overweight and obesity among children may reveal opportunities for intervention and possible prevention of obesity and chronic non-communicable diseases in later life. Studies on overweight and obesity among adolescents and adults have been done in Jamaica but data are unavailable for children six to ten years old. This study will estimate the burden of overweight and obesity among children six to ten years old in the North-East Health Region (NEHR) of Jamaica, comprising three of Jamaica's fourteen parishes which are predominantly rural with a few urban towns.

\section{SUBJECTS AND METHODS}

Setting

A list of schools in the parishes of St Ann, St Mary and Portland was obtained from the Ministry of Education, Jamaica. Ethical approval was received from the University Hospital of the West Indies/The University of the West Indies/Faculty of Medical Sciences Ethics Committee and permission for the use of primary schools was obtained from 
the Ministry of Education, Jamaica and the Principal/School Board Chairman for each school. A one-page information leaflet was sent home to the parent prior to the assessment of the children's weights and heights.

Data were collected between October 2008 and March 2009. The number of children assessed was proportional to the five- to nine-year old population per parish and location (8). Based on the 2001 population census, the proportion of children aged five to nine years per parish were as follows: St Ann 45.8\%, St Mary 31.7\% and Portland 22.5\% (8). It was proposed that each class would have at least 30 children and, with five-year age-categories or five classes (grades $1-5$ ), a total of 150 children would be assessed per school. If 40 schools were included in this study then a total of 6000 children would be assessed. Based on these criteria, the proposed number and per cent of children to be assessed per parish was as follows: 1349 (22.5\%) for Portland, 1903 (31.7\%) for St Mary, 2748 (45.8\%) for St Ann, giving a total of $6000(100.0 \%)$ for the NEHR.

Stratified random sampling was used. Schools were categorized in each parish as urban public, rural public or private. Schools were randomly selected within each stratum from each parish for participation in the study. A total of 34 schools were selected with 12 from St Ann and 11 each from St Mary and Portland. At each school, all the children (except for one private school with 14 children) attending on the day of assessment were weighed and their heights were mea-sured. The schools were stratified by grades one to five which correlated with the ages six to ten years old. The schools were the primary sampling units and the classes were the secondary sampling units. A minimum of one class was sampled per year of age. Records were obtained from the class teacher on the date of birth and age of each child.

\section{Anthropometry}

Weights were measured on a Tannita digital scale for all the children in the sampled classes. A standard weight of ten kilograms was used to calibrate and ensure accuracy of scales to the nearest $0.1 \mathrm{~kg}$. This was done before and after measuring 30 children (ie each class). Height measurements were done using a portable Leicester measuring rod from Quality Metrics (Seca, Birmingham, United Kingdom). To provide a reliable estimate of height, the average of two separate measurement values to the nearest $0.1 \mathrm{~cm}$ was used for each child.

Body mass index for age z-scores were calculated using age and gender appropriate weight and height data tables obtained from the WHO child growth standard (7). The children assessed were classified using BMI for age as underweight/thinness (z-score $<-2 \mathrm{SD}$ ), normal (z-score $-2 \mathrm{SD}$ to $1 \mathrm{SD}$ ), overweight (z-score $>1 \mathrm{SD}$ to $2 \mathrm{SD}$ ) and obese (z-score $>2 \mathrm{SD})$. These were based on the cut-off points of the WHO growth standards BMI for age 5-19 years (7).

\section{Statistical methods}

Data analysis yielded point prevalence estimates of overweight and obesity, as well as mean values for BMI-for-age, by age, gender, parish, and school location with confidence intervals (CI). Analysis of variance was used to compare means while the Pearson Chi-squared test was used to compare proportions. Odds ratios (OR) and 95\% CI were used to estimate associations between overweight and obesity, and age, gender and school location. Age and gender-adjusted odds ratios were estimated using logistic regression models. Statistical analyses were performed using SPSS 17.0 (SPSS Inc, Chicago, Illinois) and Stata version 10 (StataCorp, College Station, Texas).

\section{RESULTS}

A total of 5710 (95.2\% of proposed enrolment) children six to ten years from 34 schools were assessed for weight and height. Similar proportions of boys and girls were assessed: (boys 49.6\% [2830] and girls 50.4\% [2880]). Each age group represented about $20 \%$ of the sample (Table 1). The overall

Table 1: Basic characteristics of the study population $(n=5710)$

\begin{tabular}{|c|c|c|c|c|}
\hline Indicators & $\%$ of sample & Mean BMI & $\%$ Overweight & $\%$ Obese \\
\hline \multicolumn{5}{|l|}{ Age } \\
\hline 6 years & \multirow[t]{2}{*}{18.2} & \multirow[t]{2}{*}{15.45} & & \\
\hline $95 \% \mathrm{CI}$ & & & $7.0,10.0$ & $4.0,7.0$ \\
\hline 7 years & \multirow[t]{2}{*}{20.2} & \multirow[t]{2}{*}{15.72} & $11.1^{*}$ & \\
\hline $95 \% \mathrm{CI}$ & & & $9.0,13.0$ & $4.0,7.0$ \\
\hline 8 years & \multirow{2}{*}{20.9} & \multirow[t]{2}{*}{16.24} & $9.5^{*}$ & $6.9^{*}$ \\
\hline $95 \% \mathrm{CI}$ & & & $8.0,11.0$ & $5.0,8.0$ \\
\hline 9 years & \multirow[t]{2}{*}{21.2} & \multirow[t]{2}{*}{16.96} & $11.3 *$ & $8.7 *$ \\
\hline $95 \% \mathrm{CI}$ & & & $10.0,13.0$ & $7.0,10.0$ \\
\hline 10 years & \multirow[t]{2}{*}{19.5} & \multirow[t]{2}{*}{$17.41^{*}$} & $12.6^{*}$ & $8.6^{*}$ \\
\hline $95 \%$ CI & & & $11.0,15.0$ & $7.0,10.0$ \\
\hline \multicolumn{5}{|l|}{ Sex } \\
\hline Boys & \multirow[t]{2}{*}{49.6} & \multirow[t]{2}{*}{16.15} & 8.7 & 6.2 \\
\hline $95 \% \mathrm{CI}$ & & & $8.0,10.0$ & $5.0,7.0$ \\
\hline Girls & \multirow[t]{2}{*}{50.4} & \multirow[t]{2}{*}{$16.58^{*}$} & $12.5^{*}$ & $7.9^{*}$ \\
\hline $95 \% \mathrm{CI}$ & & & $11.0,14.0$ & $7.0,9.0$ \\
\hline \multicolumn{5}{|l|}{ Parishes } \\
\hline St Ann & \multirow[t]{2}{*}{45.8} & \multirow[t]{2}{*}{16.10} & 8.9 & \\
\hline $95 \%$ CI & & & $8.0,10.0$ & $6.0,8.0$ \\
\hline St Mary & \multirow[t]{2}{*}{31.7} & \multirow[t]{2}{*}{16.63} & 11.7 & 7.4 \\
\hline $95 \% \mathrm{CI}$ & & & $10.0,13.0$ & $6.0,9.0$ \\
\hline Portland & \multirow[t]{2}{*}{22.5} & \multirow[t]{2}{*}{16.55} & 12.5 & 6.6 \\
\hline $95 \% \mathrm{CI}$ & & & $11.0,14.0$ & $5.0,8.0$ \\
\hline \multicolumn{5}{|l|}{ School type } \\
\hline Private schools & \multirow[t]{2}{*}{9.2} & \multirow[t]{2}{*}{$17.92 *$} & $22.7 *$ & $16.2 *$ \\
\hline $95 \%$ CI & & & $19.0,26.0$ & $13.0,19.0$ \\
\hline Urban public & \multirow[t]{2}{*}{19.2} & \multirow[t]{2}{*}{$16.91 *$} & $13.0^{*}$ & $11.7 *$ \\
\hline $95 \%$ CI & & & $11.0,15.0$ & $10.0,14.0$ \\
\hline Rural public & 71.6 & $16.02 *$ & $8.4^{*}$ & $4.7^{*}$ \\
\hline $95 \% \mathrm{CI}$ & & & $8.0,9.0$ & $4.0,5.0$ \\
\hline
\end{tabular}

$p$-value: $* 0.001, \mathrm{BMI}=$ body mass index 
prevalence of over-weight and obesity was $10.6 \%(95 \% \mathrm{CI}=$ $10.0,11.0 \%)$ and $7.1 \%(95 \% \mathrm{CI}=6.0,8.0 \%)$, respectively. The prevalence of underweight was $3.6 \%(95 \% \mathrm{CI}=3.0$, $4.0 \%$ ) while $78.7 \%$ (95\% CI $=78.0,80.0 \%)$ had normal BMI-for-age category.

Overweight and obesity prevalence increased significantly, with age being $8.4 \%(95 \% \mathrm{CI}=7.0,10.0 \%)$ and $5.7 \%$ $(95 \% \mathrm{CI}=4.0,7.0 \%)$ at six years and $12.6 \%(95 \% \mathrm{CI}=11.0$, $15.0 \%)$ and $8.6 \%(95 \% \mathrm{CI}=7.0,10.0 \%)$ at 10 years, respectively (Table 1). Odds ratios for overweight $(\mathrm{OR}=1.11$, $95 \% \mathrm{CI}=1.04,1.18, p=0.001)$ and obesity $(\mathrm{OR}=1.17,95 \%$ $\mathrm{CI}=1.08,1.26, p<0.001)$ revealed an $11 \%$ and a $17 \%$ schools also had significantly higher rates $(p<0.001)$ of overweight with $22.7 \%(95 \% \mathrm{CI}=19.0,26.0 \%)$ and obesity with $16.2 \%(95 \% \mathrm{CI}=13.0,19.0 \%)$ than public schools (Table 1).

Compared to children from urban public schools, children attending private schools were two times more likely to be classified as overweight $(\mathrm{OR}=2.11,95 \% \mathrm{CI}=1.60,2.78$, $p=0.001)$ and one and half times more likely to be obese $(\mathrm{OR}=1.68,95 \% \mathrm{CI}=1.24,2.28, p<0.001)$ [Table 2]. Compared to children from urban public schools, children from rural schools were less likely to be classified as overweight $(\mathrm{OR}=0.57,95 \% \mathrm{CI}=0.46,0.70, p<0.001)$ or obese

Table 2: Relationship (odds ratio - OR) between body mass index, gender, age and schools' location $(\mathrm{n}=5710)$

\begin{tabular}{|c|c|c|c|c|c|c|}
\hline \multirow{2}{*}{ Indicators } & \multicolumn{2}{|c|}{ Underweight } & \multicolumn{2}{|c|}{ Overweight } & \multicolumn{2}{|c|}{ Obese } \\
\hline & Unadjusted & Adjusted & Unadjusted & Adjusted & Unadjusted & Adjusted \\
\hline \multicolumn{7}{|c|}{ Gender (age-adjusted) } \\
\hline Boys & 1.0 & 1.0 & 1.0 & 1.0 & 1.0 & 1.0 \\
\hline Girls & 0.82 & 0.83 & 1.51 & 1.47 & 1.36 & 1.31 \\
\hline $95 \% \mathrm{CI}$ & $0.62,1.09^{\mathrm{ns}}$ & $0.62,1.10^{\mathrm{ns}}$ & $1.27,1.80^{*}$ & $1.23,1.75^{*}$ & $1.11,1.67 *$ & $1.06,1.61^{*}$ \\
\hline \multicolumn{7}{|c|}{ Age (gender-adjusted) } \\
\hline 6 years & 1.0 & 1.0 & 1.0 & 1.0 & 1.0 & 1.0 \\
\hline $\begin{array}{l}1 \text { year age } \\
\text { Increment }\end{array}$ & 1.07 & 1.07 & 1.11 & 1.11 & 1.17 & 1.17 \\
\hline $95 \% \mathrm{CI}$ & $0.96,1.18^{\mathrm{ns}}$ & $0.96,1.18^{\mathrm{ns}}$ & $1.04,1.18^{*}$ & $1.05,1.19^{*}$ & $1.08,1.26^{*}$ & $1.09,1.26^{*}$ \\
\hline \multicolumn{7}{|c|}{ School type (age and gender-adjusted) } \\
\hline Urban public & 1.0 & 1.0 & 1.0 & 1.0 & 1.0 & 1.0 \\
\hline Private & 0.49 & 0.50 & 2.11 & 2.14 & 1.68 & 1.73 \\
\hline $95 \%$ CI & $0.20,1.19^{\mathrm{ns}}$ & $0.21,1.21^{\mathrm{ns}}$ & $1.60,2.78^{*}$ & $1.62,2.83^{*}$ & $1.24,2.28^{*}$ & $1.28,2.35^{*}$ \\
\hline Rural public & 1.27 & 1.27 & 0.57 & 0.57 & 0.35 & 0.36 \\
\hline $95 \%$ CI & $0.86,1.87^{\mathrm{ns}}$ & $0.86,1.88^{\mathrm{ns}}$ & $0.46,0.70^{*}$ & $0.47,0.71^{*}$ & $0.28,0.44^{*}$ & $0.28,0.45^{*}$ \\
\hline
\end{tabular}

$p$-value: $* 0.001$, ns - not significant (age and gender adjustments were made)

increase, respectively, in odds per year of age (Table 2). Mean BMI increased with age $(p<0.001)$ and was higher $(p$ $<0.001)$ among girls than boys. Overweight prevalence was significantly higher among girls with $12.5 \%(95 \% \mathrm{CI}=11.0$, $14.0 \%$ ) than boys with $8.7 \%$ [95\% CI $=8.0,10.0 \%$ ] (Table 1). This was also shown by the odds of overweight (OR = $1.51,95 \% \mathrm{CI}=1.27,1.80, p<0.001)$ and obesity $(\mathrm{OR}=$ $1.36,95 \% \mathrm{CI}=1.11,1.67, p=0.003$ ) being 1.5 and 1.4 times higher among girls than boys, respectively (Table 2).

Within NEHR, Portland has the highest overweight prevalence of $12.5 \%(95 \% \mathrm{CI}=11.0 \%, 14.0 \%)$ followed by St Mary with $11.7 \%(95 \% \mathrm{CI}=10.0,13.0 \%)$, whereas St Mary has the highest obesity prevalence with 7.4\% (95\% CI $=6.0,9.0 \%)$ followed by St Ann with 7.1\% (95\% CI = 6.0, $8.0 \%)$. Both overweight $-13.0 \%(95 \% \mathrm{CI}=11.0,15.0 \%)$ and obesity $-11.7 \%(95 \% \mathrm{CI}=10.0,14.0 \%)$ were significantly more prevalent in urban-public schools than in ruralpublic schools with $8.4 \%(95 \% \mathrm{CI}=8.0,9.0 \%)$ overweight and $4.7 \%(95 \% \mathrm{CI}=4.0,5.0 \%)$ obese $(p<0.001)$. Private
$(\mathrm{OR}=0.35,95 \% \mathrm{CI}=0.28,0.44, p<0.001)$. After adjusting for age and gender, the results still remained statistically significant (Table 2).

\section{DISCUSSION}

The aim of this study was to estimate the prevalence of overweight and obesity among children six to ten years old in the NEHR of Jamaica. St Ann, St Mary and Portland are predominantly rural parishes but with clearly defined urban centres. The schools were categorized as either urban, rural (both public) or private in order to carry out contrasts of the prevalence of overweight and obesity in different contexts (urban vs rural, private $v s$ public). Comparison was also done between boys and girls. The six to ten-year age group was chosen because data for this age range are not readily available in Jamaica. Studies have indicated that interventions done at an early age to establish healthy habits can have more positive and longer lasting results than those done with adults 
$(9,10)$. The response rate for this study was $95.2 \%$, which increases its power.

Results from this study are consistent with the findings from other published studies from Jamaica, the Caribbean and farther afield (11-15). Our findings that approximately one in five $(17.7 \%)$ children six to ten years old were classified as overweight/obese is supported by a comparative study of children 10-11 years in Quebec, Canada, and Jamaica which found that approximately one-quarter $(26 \%)$ of children 10 years old from Québec, Canada, and one-tenth (11\%) of children 10-11 years old from Jamaica were overweight or obese (11). Wang et al reported $16 \%$ of children and adolescents overweight and $34 \%$ at risk of overweight in the USA (14). Odgen et al also found $17.1 \%$ of children and adolescents in the USA to be overweight (15).

This study found that overweight and obesity risk increases with age; children at age ten years old were 1.5 times more likely to be overweight than children at age six years old (Table 2). As children age, the risk of being overweight and obese increases which is in keeping with the overweight and obesity risk among the adult population $(14,15)$.

Our finding that children attending private and urban public schools had significantly higher rates of overweight and obesity than those attending rural schools is in keeping with those of Fox et al whose work revealed that urban adolescent boys and girls in Jamaica were significantly more likely to be overweight or obese than their rural counterparts (13). Attending rural schools seemed to protect children from being overweight or obese. In the 13-15-year age group, $11 \%$ of urban girls were obese compared with 3-4\% of their rural counterparts (13). Fox et al also found that $7 \%$ of adolescents aged 10-15 years were overweight and almost $4 \%$ were obese. At all ages, more girls than boys were obese (13).

A study done in Bapol, Islamic Republic of Iran, found a high prevalence of overweight and obesity among children 7-12 years old with higher prevalence among private-school educated children compared with public-school educated students [age adjusted $\mathrm{OR}=2.17,95 \% \mathrm{CI}=1.47,3.18$ ] (7). This is in keeping with findings in this study where children attending private schools had significantly higher overweight/obesity rates.

The Bapol, Iran, study found a lower prevalence of overweight and obesity among girls which contradicts the findings in this study. The present study found that mean BMI for age was higher among girls than boys $(p<0.001)$. Other studies (13) also found higher rates of overweight and obesity among girls.

One limitation of this study is that at one private school, only 14 children were assessed, due to parental nonresponse for participation.

The policy on the nutrition surveillance of children zero to five years in the Jamaican public health sector needs to be reviewed to consider the inclusion of children up to age
10 years. Intervention for the prevention of overweight and obesity which usually focusses on adolescents ages 10 to 15 years needs to be reviewed to include children from age six years through to the preadolescent age. A case-control study to identify risk factors for childhood overweight and obesity has been done and results will be available shortly. An intervention study to help in the reduction of overweight and obesity among children will also be done. Intervention implemented at this age could help in reducing the prevalence of overweight and obesity during the adolescent years and beyond and provide opportunities for the possible prevention of chronic non-communicable diseases in later life.

\section{ACKNOWLEDGEMENTS}

We wish to say special thanks to: The University of the West Indies, the St Ann Health Department/North East Regional Health Authority/Ministry of Health, Jamaica and the Pan American Health and Education Foundation (PAHEF) who provided funding for this project; to all the parents and children who consented to be part of this study; to the Ministry of Education and School Administrators who gave permission for the use of schools in this study; to the health staff in Portland, St Mary and St Ann who assisted with data collection; and to families, friends and co-workers for their support.

\section{REFERENCES}

1. American Academy of Child and Adolescent Psychiatry (AACAP). Obesity in children and teens. Facts for Families no. 79. American Academy of Child and Adolescent Psychiatry; 2011 March. Available from: http://www.aacap.org/AACAP/Families_and_Youth/Facts_for Families/Facts_for_Families_Pages/Obesity_In_Children_And_Teens_ 79.aspx

2. World Health Organization (WHO). Fight childhood obesity to help prevent diabetes. Geneva; WHO; 2004

3. World Health Organization. Prevalence of excess body weight and obesity in children and adolescents. Fact sheet No 2.3. European Environment and Health Information System. Copenhagen, Denmark: World Health Organization (Regional Office for Europe); 2007.

4. Caribbean Food and Nutrition Institute (CFNI). The many faces of obesity. In: Nyam News. Kingston: CFNI, PAHO/WHO; 2001.

5. World Health Organization. Obesity and overweight, Fact sheet No. 311. Geneva: WHO; 2006.

6. World Health Organization. Multicentre Growth Reference Study Group. WHO child growth standards: length/height-for-age, weightfor-age, weight-for-length, weight-for-height, and body mass index-forage (5-19 years): Methods and Development. Geneva. WHO; 2006.

7. Hajian-Tilaki KO, Sajjadi P, Razavi A. Prevalence of overweight and obesity and associated risk factors in urban primary-school children in Babol, Islamic Republic of Iran. East Mediterr Health J 2011; 17: 109-14.

8. Statistical Institute of Jamaica (STATIN). Population census 2001 Jamaica, Volume 2, Age and Sex. Kingston: Statistical Institute of Jamaica; 2003: 143-219.

9. Epstein LH, Valoski AM, Kalarchian MA, McCurley J. Do children lose and maintain weight easier than adults: a comparison of child and parent weight changes from six months to ten years. Obesity Research 1995; 3: 411-17.

10. Improving Chronic Illness Care. The Chronic Care Model. Seattle: Improving Chronic Illness Care; 2008. Available from: http:// improvingchroniccare.org/index.php? $\mathrm{p}=$ The_Chronic_Care_Model\&s $=2$ 
11. Dubois L, Francis D, Burnier D, Tatone-Tokuda F, Girard M, GordonStrachan $\mathrm{G}$ et al. Household food insecurity and childhood overweight in Jamaica and Québec: a gender-based analysis. BMC Public Health 2011; 11: 199. doi:10.1186/1471-2458-11-199. Available from: http://www.biomedcentral.com/1471-2458/11/199

12. Ministry of Health $(\mathrm{MoH})$, Bahamas. Ministry of Health, Commonwealth of The Bahamas in collaboration with the CFNI, PAHO/WHO National health and nutrition survey 1988-89. Nassau, Bahamas: Health Information Coordinating Services, MoH; 1989: 913, 103 .

13. Fox K, Gordon-Strachan G. Jamaican Youth Risk and Resiliency Behaviour Survey 2005. School-based survey on risk and resiliency behaviours of 10-15 year olds. USAID; Measure Evaluation; $\mathrm{MOH}$,
Jamaica; 2007. Available from: http://pdf.usaid.gov/pdf_docs/ PNADJ 236.pdf

14. Wang Y, Beydoun MA. The obesity epidemic in the United States gender, age, socioeconomic, racial/ethnic, and geographic characteristics: a systematic review and meta-regression analysis. Epidemiologic Reviews 2007; 29: 6-28. doi: 10.1093/epirev/mxm007. Available from: http://epirev.oxfordjournals.org/content/29/1/6.ful.pdfl

15. Ogden CL, Carroll MD, Curtin LR, McDowell MA, Tabak CJ, Flegal KM. Prevalence of overweight and obesity in the United States, 1990-2004. JAMA 2006; 295: 1549-55. doi:10.1001/jama. 295.13.1549. Available from: http://jama.jamanetwork.com/article. aspx? articleid $=202627$ 